日植病報 XXVII，（4）:204～213（1962）

\title{
イネ萎縮病ウイルスに関する研究 (続報)一II
}

木 村 郁 夫*

Ikuo Kimura : Further studies on the rice dwarf virus.- $\mathrm{II}$

実験材料特よび方法は前報のと扣りである。

発育鶏卵培養法の御指導を賜わつた北海道大学医学 部附属病院眼科の越智通成医学博士, 超遠心分離の操 作を御指導下さつた同学部第 1 生理学教室斎藤大雄氏 につつしんで感謝の意を表する。

\section{ウイルスの精製}

最近までイネ萎縮病ウイルスの形態や大きさについ ては全く不明であつた。これを研究するために罹病植 物扣よび保毒虫の控汁液からウイルス粒子を分離する ことを企てた。

\section{低速遠沈試験}

高速遠沈と低速遠沈とを組み合わせた分画遠心分離 に执いて, ウイルス粒子の損失が最も少なく, しか子 ウイルス粒子以外の粒子をできるだけ多く除去する適 当な低速遠心力を定めることがまず必要である。

実験 1. 罹病イネの茎葉を磨䂥して, 第 1 図のごと

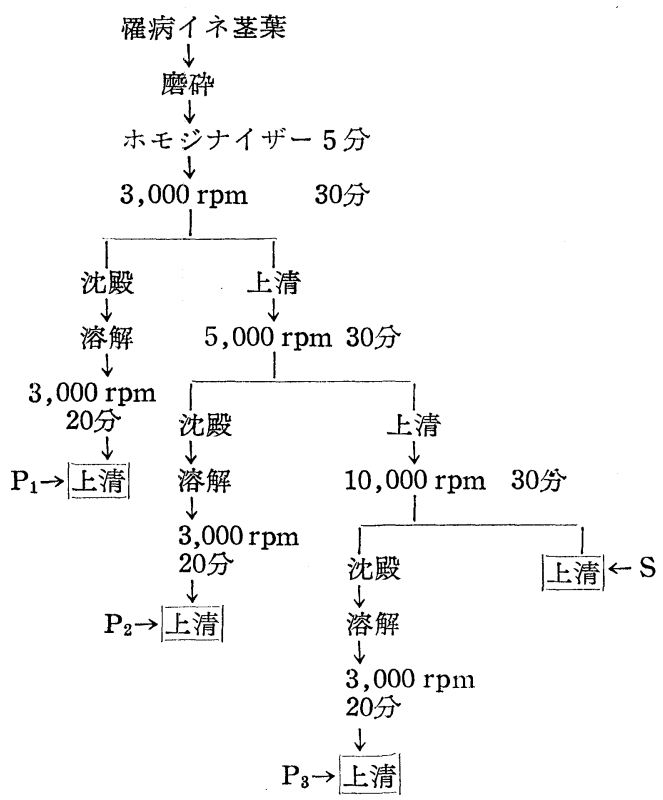

第 1 図 低速遠心分離
く遠心分離を行なつた。

ここで得た試料 $\mathrm{P}_{1} \sim \mathrm{P}_{3}$ 打よび $\mathrm{S}$ をれぞれ無毒虫 に注射した。その結果は第 1 表のと拈りである。

第 1 表 接種試験結果

\begin{tabular}{c|c|c|c}
\hline 供試試料 & 注射虫数 & $\begin{array}{c}\text { 20日以上生存虫数 } \\
\text { 感染虫数 }\end{array}$ \\
\hline $\mathrm{P}_{1}$ & 50 & 25 & 0 \\
$\mathrm{P}_{2}$ & 50 & 22 & 0 \\
$\mathrm{P}_{3}$ & 50 & 22 & 1 \\
$\mathrm{~S}$ & 50 & 23 & 4 \\
\hline
\end{tabular}

この結果より $\mathrm{P}_{3}$ 执よびSは感染力を有しウイルス が含まれていることが認められた。

実験 2 . 保毒虫を磨砕して, 第 2 図のごとく遠心分 離を行なつた。

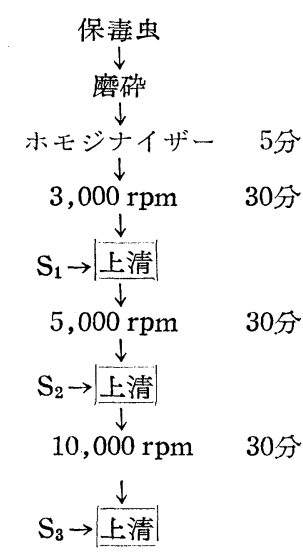

第 2 図 低速遠心分離

上述の $\mathrm{S}_{1} \sim \mathrm{S}_{3}$ の 1 部をとり無毒虫に注射した。そ の結果は第 2 表に示すと扣りである。

この結果によると $\mathrm{S}_{1} \sim \mathrm{S}_{3}$ の感染力は同程度であつ て, この一連の遠心分離操作ではウイルスが最後まで 上清に含まれていることがわかつた。

以上低速遠沈試験では $5,000 \mathrm{rpm} 30$ 分遠心分離を 行なつてもウイルスは沈殿せず, $10,000 \mathrm{rpm} 30$ 分で はわずかに沈殿するが大部分のウイルスは上清に含ま

* 北海道大学農学部 
第 2 表 接種試験結果

\begin{tabular}{c|c|c|c}
\hline 供試試料 & 注射虫数 & $\begin{array}{c}20 \text { 日以上 } \\
\text { 生存虫数 }\end{array}$ & 感染虫数 \\
\hline $\mathrm{S}_{1}$ & 25 & 13 & 2 \\
$\mathrm{~S}_{2}$ & 25 & 17 & 3 \\
$\mathrm{~S}_{3}$ & 25 & 18 & 3 \\
\hline
\end{tabular}

れることがわからた。したがつてウイルスの損失の少 ない低速遠沈の限界は 5,000 rpm 30 分であるが, $10,000 \mathrm{rpm} 30$ 分を用いてもウイルスの損失はわずか であると考えられる。

\section{高速遠沈試験}

磨砕汁液中のウイルス粒子を沈殿させるに必要な遠 心力を知るために以下の実験を行なつた。

実験 1 . 䍜病イネの磨砕液を第 3 図のごとく遠心 分離を行なつた。

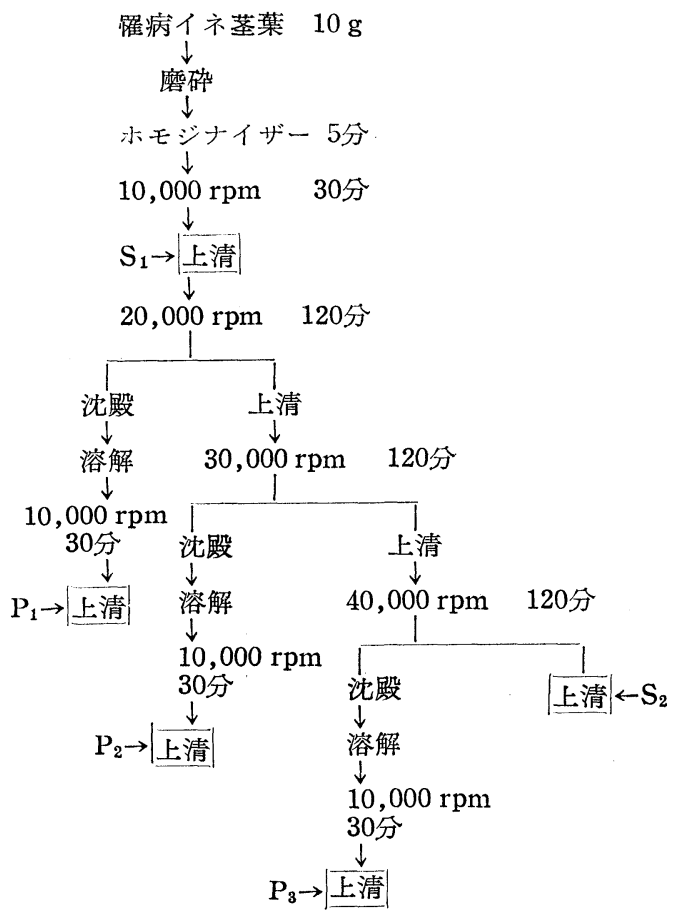

第 3 図高速遠心分離

この一連の操作で得られた試料 $\mathrm{S}_{1} \sim \mathrm{S}_{2}$ 执よび $\mathrm{P}_{1}$ 〜 $\mathrm{P}_{3}$ をそれぞれ無毒虫に注射した。その結果は第 3 表 に示すと扣りである。

この結果より $\mathrm{S}_{1}$ に含まれるウイルス粒子の多くは $\mathrm{P}_{1}$ に存し, $\mathrm{P}_{2}, \mathrm{P}_{3}$ 扎よび $\mathrm{S}_{2}$ には少量が含まれてい ることがわかつた。

実験 2. 前実験同様の遠心分 離を保毒虫の 磨砕液 を用いて行なつた。その結果は第 4 表に示すと扣りで ある。
第 3 表 接種試験結果

\begin{tabular}{c|c|c|c}
\hline 供試試料 & 注射虫数 & $\begin{array}{c}\text { 20日以上生存虫数 } \\
\text { 感染虫数 }\end{array}$ \\
\hline $\mathrm{S}_{1}$ & 60 & 46 & 12 \\
$\mathrm{P}_{1}$ & 60 & 45 & 6 \\
$\mathrm{P}_{2}$ & 60 & 42 & 2 \\
$\mathrm{P}_{3}$ & 60 & 38 & 1 \\
$\mathrm{~S}_{2}$ & 60 & 31 & 1 \\
\hline
\end{tabular}

第 4 表 接種試験結果

\begin{tabular}{c|c|c|c}
\hline \hline 供試試料 & 注射虫数 & $\begin{array}{c}\text { 20日以上 } \\
\text { 生存虫数 }\end{array}$ & 感染虫数 \\
\hline $\mathrm{S}_{1}$ & 30 & 22 & 4 \\
$\mathrm{P}_{1}$ & 30 & 21 & 2 \\
$\mathrm{P}_{2}$ & 30 & 19 & 0 \\
$\mathrm{P}_{3}$ & 30 & 17 & 1 \\
$\mathrm{~S}_{2}$ & 30 & 15 & 0 \\
\hline
\end{tabular}

第 4 表の結果によれば，前実験の結果と同じく， $\mathrm{S}_{1}$ に含まれるウイルスの多くは $\mathrm{P}_{1}$ に存し， $\mathrm{P}_{2}, \mathrm{P}_{3}$ 就よ び $\mathrm{S}_{2}$ にはほとんど存しないことがわかつた。

実験 3. 保毒虫を用いて，第 4 図のごとく遠心分 離を行なつた。

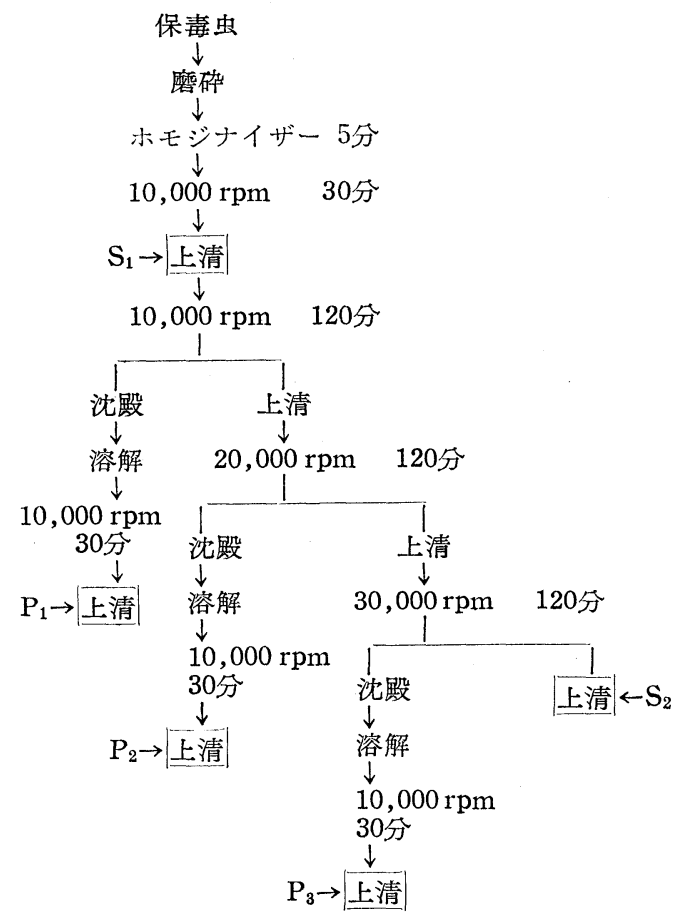

第 4 図高速遠心分離

ここで得られた試料 $\mathrm{P}_{1} \sim \mathrm{P}_{3}$ および $\mathrm{S}_{1} \sim \mathrm{S}_{2}$ をとれ ぞれ無毒虫に注射した。その結果は第 5 表に示すと特 
第 5 表 接種試験結果

\begin{tabular}{c|c|c|c}
\hline 供試試料 & 注射虫数 & $\begin{array}{c}\text { 20日以上 } \\
\text { 生存虫数 }\end{array}$ & 感染虫数 \\
\hline $\mathrm{S}_{1}$ & 30 & 16 & 3 \\
$\mathrm{P}_{1}$ & 30 & 16 & 2 \\
$\mathrm{P}_{2}$ & 30 & 16 & 2 \\
$\mathrm{P}_{3}$ & 30 & 15 & 0 \\
$\mathrm{~S}_{2}$ & 30 & 12 & 0 \\
\hline
\end{tabular}

りである。

この結果より $\mathrm{S}_{1}$ に含まれるウイルスは $\mathrm{P}_{1}$ そ $\mathrm{P}_{2}$ に同程度に含まれていることがわかつた。

以上高速遠沈試験の結果を合わせ考えると，20,000 rpm 120 分遠心分離を行な5 と大部分のウイルス粒子 が沈殿することと，また 10,000 rpm 120 分では沈殿， 上清ともほぼ同量のウイルスを含むことがわかつた。

\section{沈降速度}

前実験に括いて，20,000 rpm 120 分遠心分離によ つて得た沈殿にウイルス活性が高く，この試料中には ウイルス粒子が最も多く含まれていると考えられた。 この試料について分析用超遠心機を用いて，沈降図を 撮影し，試料の純度を見る実験を行なつた。沈降定数 (St）は次式により算出した ${ }^{12) 。 ~}$

$$
\mathrm{St}=\frac{2\left(x_{2}-x_{1}\right)}{\left(x_{2}+x_{1}\right) \omega^{2}\left(\mathrm{t}_{2}-\mathrm{t}_{1}\right)}
$$

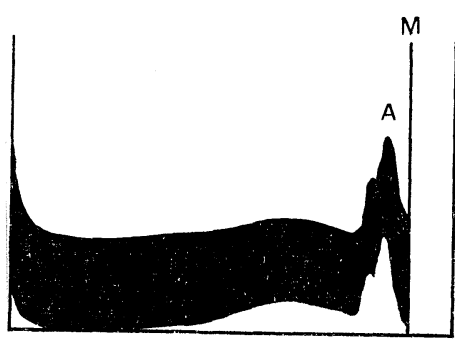

健全イネ $x$ : 回転中心より peak までの距離 $\mathrm{cm}$

$\mathrm{t}:$ 秒

$\omega: \mathrm{N} \pi / 30(\mathrm{~N}=\mathrm{rpm})$

実験 1. 罹病イネ茎葉を磨砕して第 5 困のごとく 精製を行なつた。

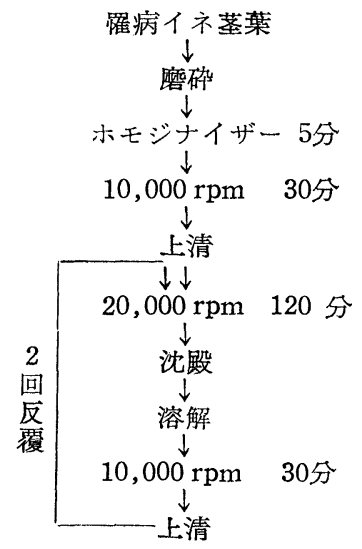

第 5 区 分画遠心分離

ここで最後に得た上清を Spinco E 型超遠心機の分 析用セルに入れ，20,410 rpm（Max. 30,400 g) で遠 心分離を行なつて，4分和きに㴧降図を撮影した。こ れらの沈降図の 1 部は第 6 図に示すと招りである。

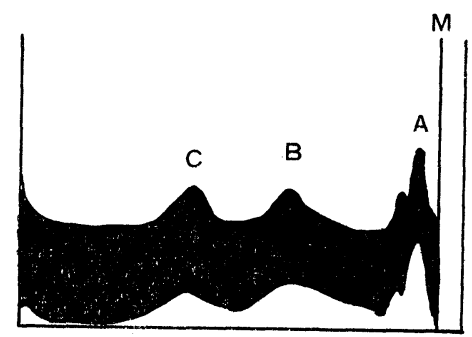

瞿病イネ
第 6 図

この結果によれば peak B 特よびCは曜病イネ試料 にのみ存し, 健全イネ試料には存在しなかつた。しか し peak A は健病両試料に存し, イネ組織内の正常 細胞構成成分之考之られる。䍜病イネ試料の peak B 牤よびCの沘降定数（St）は次のと打りである。

peak C St $=468 \times 10^{-13}$ (平均)

peak B St $=318 \times 10^{-13}$ (平均)

実験 2. 前実験で得た試料にはウイルス以外の成 分と考兄られるるのが相当混在していたので，ここで は第7図のごとく遠心分離を行なつた。
ここで最後に得た上清を分析用セルに入れ，20,410 $\mathrm{rpm}$ で遠心分離を行なつて，2 分扣きに沈降図を撮 影した。その1 部は第 8 図に示すと扬りである。

この結果によると瞿病イネ試料には peak が1つ現 われたが，健全イネ試料には peakが 1 つる現われな かつた。この䍜病イネ試料の peak の沈降定数 $(\mathrm{St})$ の 平均は次のようであつた。

$$
\mathrm{St}=405 \times 10^{-13}
$$

この実験に現われた peak は前実験の peak C に相 当するものと考学られる。 

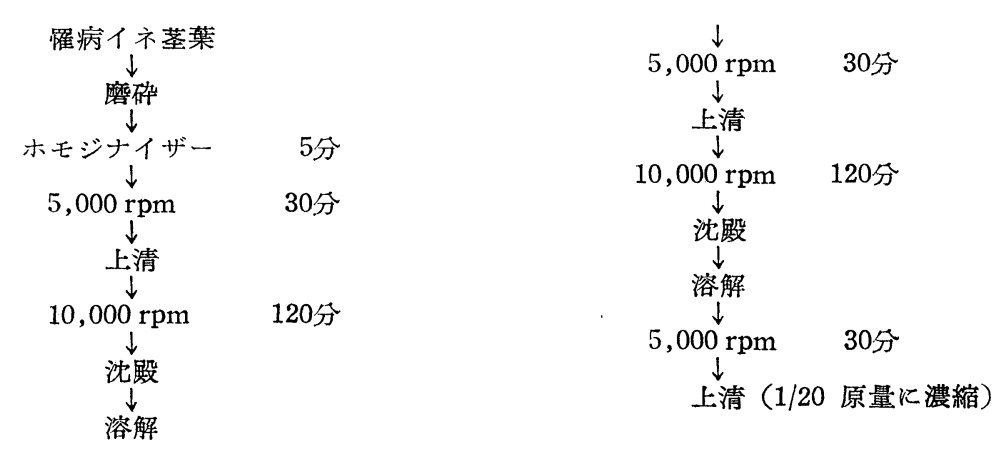

第 7 圀 分画遠心分離

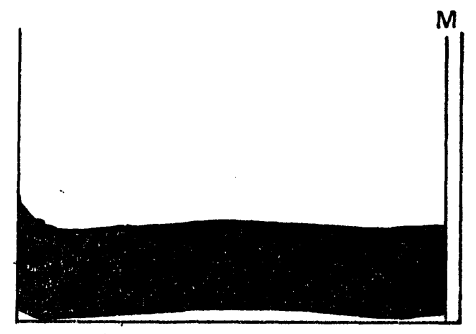

健全イネ

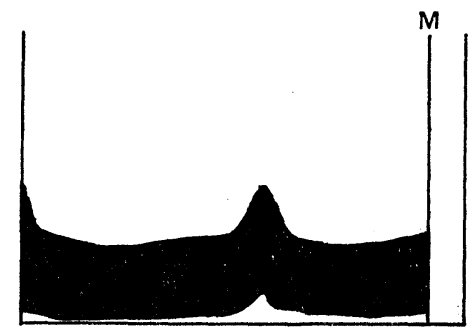

罹病イネ

第 8 図 沈降図形

\section{沈降時間}

沈降传要する時間は溶媒に対する溶質の沘降定数が わかればつぎの式から算出することができる。

$$
\begin{aligned}
& \mathrm{t}=\frac{1,521}{\mathrm{SPi}} \text { (分) } \\
& \text { ただし } \mathrm{P} i=\frac{(\mathrm{rpm})^{2}}{\log _{\theta} \mathrm{R}_{2}-\log _{\theta} \mathrm{R}_{1}} \\
& \mathrm{~S}: \text { 沈降定数/秒 } \\
& \mathrm{R}_{1}: \text { 回転中心から tube までの最短距離 } \mathrm{cm} \\
& \mathrm{R}_{2}: \quad \text { "最長距離 } \mathrm{cm}
\end{aligned}
$$

それで $\mathrm{St}=468 \times 10^{-13}$ として日立 $40 \mathrm{P}$ 型超遠心 機の RP-40 の rotor を用いて回転数を $20,000 \mathrm{rpm}$ とすると上式より，この粒子が澉降汇要する時間は 62 分となる。

\section{反覆精製}

分画遠心分離を反覆した場合に試料のウイルス活性 が変化するかどらかを知るため以下の実験を行なつ た。

実験 1. 罹病イネ茎葉を磨砕して, 第 9 図のごと く反覆して遠心分離を行なつた。

この一連の操作で得られた対照, 1 回抢よび 2 回精 製の試料をそれぞれ無毒虫に注射した。その結果は第

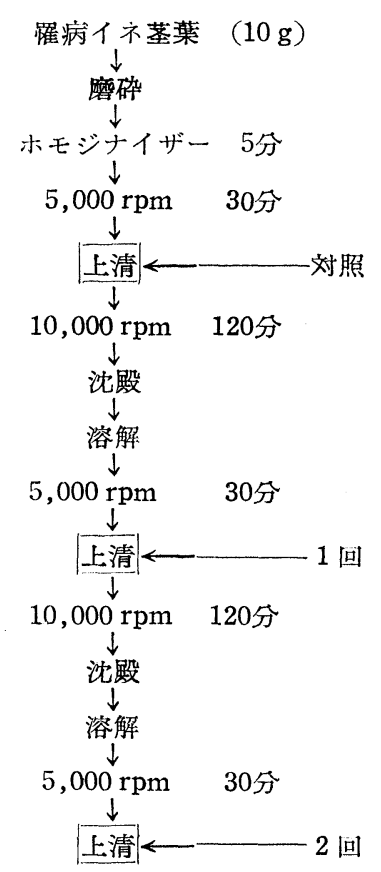

第 9 四 反覆遠心分離

6 表に示すと扣りである。

この結果より，精製 1 回で濃縮したウイルス液は感 
第 6 表 反覆精製液の接種試験結果

\begin{tabular}{c|c|c|c|c}
\hline 反覆回数 & 稀釈倍数 & 注射虫数 & $\begin{array}{c}\text { 20日以上 } \\
\text { 生存虫数 }\end{array}$ & 感染虫数 \\
\hline 刘 照 & 5 & 55 & 41 & 4 \\
1 & $1 / 5$ & 55 & 35 & 6 \\
2 & $1 / 10$ & 55 & 25 & 2 \\
\hline
\end{tabular}

染率が高いが 2 回精製したものは濃縮しても感染率が 低下することがわかつた。

実験 2. 前実験同様反覆精製を行なつた。

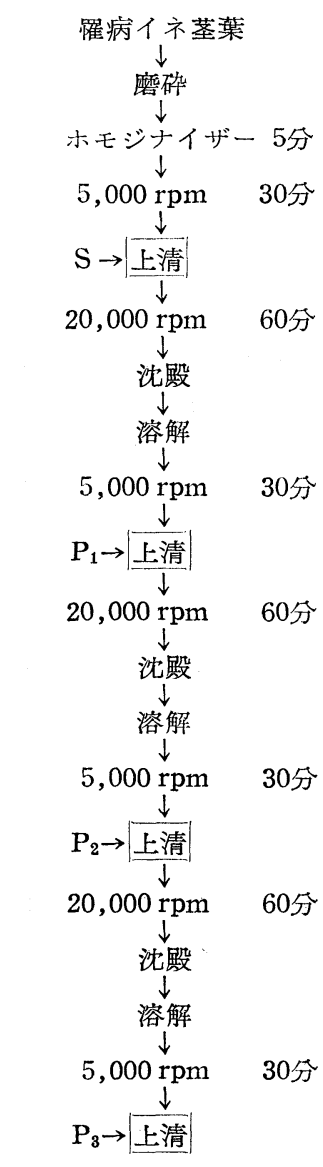

第 10 図 反覆遠心分離

ここで得た試料 $\mathrm{S}$ 打よび $\mathrm{P}_{1} \sim \mathrm{P}_{3}$ をとれぞれ無毒虫 に注射した。その結果は第 7 表に示すと特りである。

この結果よりウイルス液は精製 1 回で濃縮すると感 染率が少し高まり，2 回以上精製すれば濃縮しても感 染力が低下することがわかつた。

\section{ウイルス液からの核酸抽出}

Kirby は哺乳動物組織からリボ核酸を取り出すため
第 7 表 反覆精製液の接種試験結果

\begin{tabular}{c|r|c|c|c}
\hline \hline 供試試料 & 稀釈倍数 & 注射虫数 & $\begin{array}{c}\text { 20日以上 } \\
\text { 生存虫数 }\end{array}$ & 感染虫数 \\
\hline $\mathrm{S}$ & 5 & 30 & 16 & 2 \\
$\mathrm{P}_{1}$ & 5 & 30 & 18 & 2 \\
$\mathrm{P}_{1}$ & $1 / 10$ & 30 & 17 & 3 \\
$\mathrm{P}_{2}$ & $1 / 10$ & 30 & 16 & 0 \\
$\mathrm{P}_{3}$ & $1 / 10$ & 30 & 12 & 1 \\
\hline
\end{tabular}

にフェノールを加えて振とうし，遠心分離によつて除 タンパクを行ない，水層をとり，エタノールで RNA を沈殿させた ノール法を用いてタバュモザイク病ウイルスから核酸 (RNA) をタンパクを含まない標品としてとり出し, これをNicotiana glutinosaに接種して感染せしめるこ とに成功した ${ }^{8) 9)}$ 。また Fraenkel-Conrat らもタバュ モザイク病ウイルスを sodium dodecyl sulfate で処 理して核酸を分離し，この核酸が感染力を有すること を報告した6)。その後これらの方法によつて，多くの 植物ウイルス粒子和よび罹病組織から核酸が取り出さ れている。

ここでは Gierer und Schramm が用いたものに類 似の方法を用いて， 女る程度に精製したウイルス液か ら核酸を抽出せんとして実験を行なつた。

実験 1. 罹病イネ茎葉を磨砕し，5,000 rpm 30 分 と $20,000 \mathrm{rpm} 60$ 分の分画遠心分離によつて部分的 精製を行なつた試料から核酸の抽出を行なつた。すな

(部分的精製ウイルス液) $+($ 水飽和フェノール) $(1: 1)$ 10分間振と5

$$
5,000 \mathrm{rpm} 10 \text { 分 }
$$

水層をとり少量のフェノ福をを加えて 10 分間振とう

$$
5,000 \underset{\downarrow}{\mathrm{rpm}} 10 \text { 分 }
$$

水層をとりェーテルを加えて振と5（5分）3回

$$
20,000 \underset{\substack{\downarrow \\ \text { 上清 }}}{\downarrow} 30 \text { 分 }
$$

終末 $1 \mathrm{M} \mathrm{NaCl}$ を加えて 1 時間静置

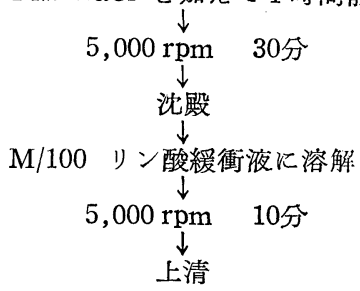

第 11 図 核酸の抽出 
わち, 精製ウイルス液と等量の水飽和フェノールを加 えて 10 分間強く振と 5 し, 遠心分離 $(5,000 \mathrm{rpm} 10$ 分）して水層をとり，少量のフェノールを加えて 10 分間振と 乙, 遠心分離 $(5,000 \mathrm{rpm} 10$ 分) して水 層をとり等量以上のェーテルを加えてフェノールを除 < ( 3 回反覆)。最後に 遠心分離 後水層に 終末 $1 \mathrm{M}$ $\mathrm{NaCl}$ を加えて 1 時間冷蔵庫内 $\left(0 \sim 4^{\circ} \mathrm{C}\right)$ に静置し, 遠心分離して沈殿を集め, リン酸緩衝液で溶解し，さ らに軽く遠心分離して上清を得る。

ここで得た抽出液 (上清) と部分的精製ウイルス液 とを無毒ヨコバイに注射した。その結果は第 8 表に示 すと拈りである。

第 8 表 抽出液の接種試験結果

\begin{tabular}{l|c|c|c|c}
\hline 供試試料 & 稀釈倍数 & 注射虫数 & $\begin{array}{c}20 \text { 日以上 } \\
\text { 生存虫数 }\end{array}$ & 感染虫数 \\
\hline 抽 出 液 & $1 / 20$ & 70 & 31 & 2 \\
ウイルス液 & 5 & 60 & 26 & 4 \\
\hline
\end{tabular}

抽出液を 70 頭のヨコバイに注射したうち 2 頭, ウ イルス液の方は 60 頭注射したうち 4 頭がそれぞれ感 染を起こした。

同一試料について血清反応を試みた結果は第 9 表に 示すと拈りである。

第 9 表 沈降反応

\begin{tabular}{l|l|l|l|l|l|l|l|l|l|}
\hline \hline $\begin{array}{l}\text { 抗血清終末 } \\
\text { 稀釈倍数 }\end{array}$ & 16 & 32 & 64 & 128 & 256 & 512 & 1024 & 2048 & 対照 \\
抽 出 液 & - & - & - & - & - & - & - & - & - \\
ウイルス液 & $+H$ & H & + & + & + & + & + & - & - \\
\hline
\end{tabular}

抽出液 : $\times 1 / 5$, ウイルス液 $: \times 5$

この結果の示すごとく，ウイルス液は $1 / 1024$ まで 沈殿反応十であるのに, 抽出液は全く反応を示さなか つた。

また同一試料の紫外部吸収度を測定したところ第 12 図に示すと拈りで, これによると $270 \mathrm{rpm}$ にpeak が 認められた。

実験 2. 前実験同様部分的精製 ウイルス液から第 13 図のごとき手順で核酸の抽出を行なつた。

そして最後に得られた抽出液およびウイルス液を無 毒虫に注射した。その結果は第 10 表に示すと扣りで ある。

この結果, 抽出液を 120 頭に注射したが 1 頭も感 染しなかつた。

同一試料について血清反応を見たが，沈降反応が認 められなかつた。またこの試料の紫外部吸収度を測定

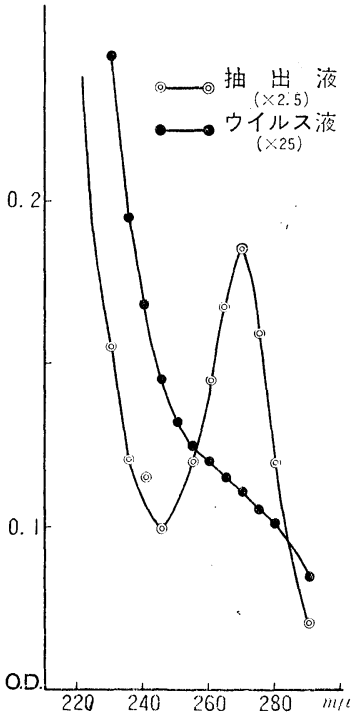

第 12 図紫外部吸収曲線

(部分的精製ウイルス液) $\underset{\downarrow}{\dagger}($ 水飽和フェノール) $(1: 1)$ 15分振と 5

$$
5,000 \mathrm{rpm} 10 \text { 分 }
$$

水層をとり少量のフェノ $\frac{\downarrow}{\downarrow}$ ルを加えて 7 分間振と5

$$
5,000 \underset{\downarrow}{\mathrm{rpm}} 10 \text { 分 }
$$

水層をとりエーテルを加えて振と5（3回）

$$
5,000 \underset{\downarrow}{\mathrm{rpm}} 10 \text { 分 }
$$

水層をとり $\mathrm{pH} 3.5$ にし終末 $50 \%$ エタノールで沈殿 1 時間冷室内静置

$$
\begin{gathered}
10,000 \underset{\downarrow}{\mathrm{rpm}} \\
\downarrow \\
\text { 沈殿 } \\
\downarrow \\
\text { 溶解 } \\
\end{gathered}
$$

pH 7.2 にし終末 $35 \%$ エタノールで沈殿 冷室内 30 分静置

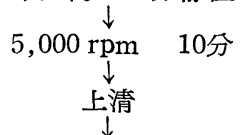

pH 3.5 にし終末 $50 \%$ エタノールで沈䬺 30 分冷室内静置

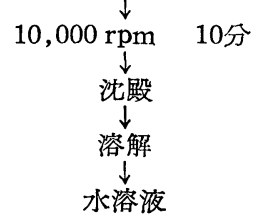

第 13 図核酸の抽出 
第 10 表 抽出液の接種試験結果

\begin{tabular}{l|r|r|c|c}
\hline \hline 供試試料 & 稀釈倍数 & 注射虫数 & $\begin{array}{c}20 \text { 日以上生存虫数 } \\
\text { 感染虫数 }\end{array}$ \\
\hline 抽 出 液 & $1 / 20$ & 120 & 37 & 0 \\
ウイルス液 & 5 & 90 & 26 & 6 \\
\hline
\end{tabular}

した結果は第 14 図に示すと括りで, $258 \mathrm{~m} \mu$ に peak が現われ，核酸の吸収曲線なることを示した。

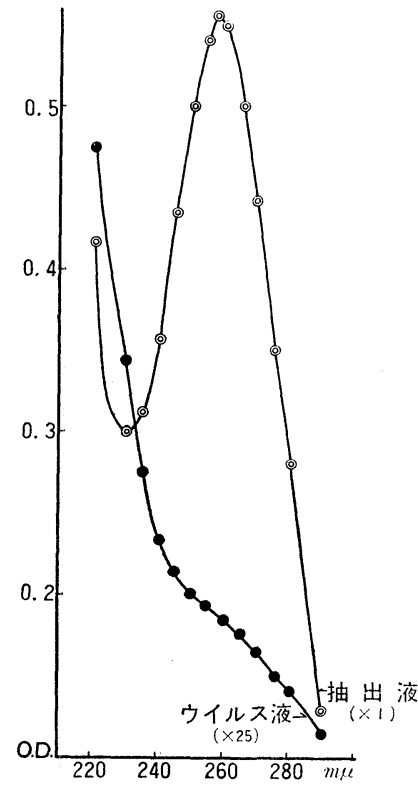

第 14 図 紫外部吸収曲線

\section{血清学的研究}

Black and Brakke は wound tumor virus を分画 遠心分離とショ糖溶液による density gradient colu$\mathrm{mn}$ 中で電気泳動を行なつて純化することに成功し
た。そしてこの精製ウイルスを Adjuvant と混合して 家鬼に注射して抗血清を得たことを報告している3)。

著者は部分的精製イネ萎縮病ウイルスと Adjuvant とを混合して家雨に注射し, 抗血清を得んとしてこの 研究を行なつた。

実験 1. 罹病イネ葉を用いて，第 15 図のごとく 精製を行なつた。

罹病イネ荃葉 $25 \mathrm{~g}$
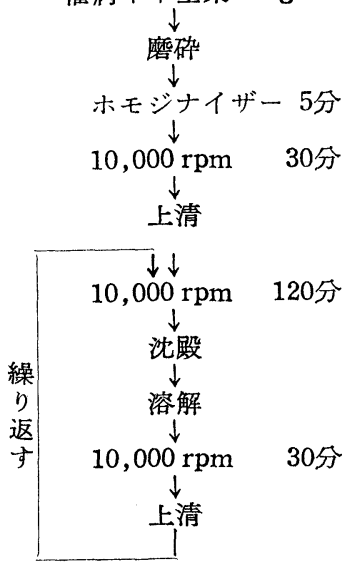

第 15 図 分画遠心分離

この最後に得られた上清に同量の Adjuvantを混合 して, 家鬼の後肢の筋内内に注射した。注射後 3 週拉 よび 5 週目に 1 部採血を行なつて, 力価検定を行なつ た。その結果は第 11 表拈よび第 12 表に示すと括り である。

この結果によると, 注射後 3 週目の血清は $1 / 512$ ま で， 5 週目の血清は $1 / 1024$ まで沈降反応を示した。

実験 2. 前実験同様にして得た部分的精製ウイル ス液と Bact Adjuvantを混合して前実験に用いた家

第 11 表 沈降反応（3 週目採血）

\begin{tabular}{|c|c|c|c|c|c|c|c|c|c|c|}
\hline $\begin{array}{l}\text { 抗血清終末 } \\
\text { 稀 彩 倍数 }\end{array}$ & 16 & 32 & 64 & 128 & 256 & 512 & 1024 & 2048 & 4096 & 対照 \\
\hline 羅病イネ汁液 & $H$ & + & + & + & + & + & \pm & - & - & - \\
\hline 健全イネ汁液 & - & - & - & - & - & - & - & - & - & - \\
\hline
\end{tabular}

抗原稀釈倍数： 5 倍

第 12 表 沈降反応 ( 5 週目採血)

\begin{tabular}{|c|c|c|c|c|c|c|c|c|c|c|}
\hline $\begin{array}{l}\text { 抗血清終末 } \\
\text { 稀 釈 倍 数 }\end{array}$ & 16 & 32 & 64 & 128 & 256 & 512 & 1024 & 2048 & 4096 & 対照 \\
\hline 罹病イネ汁液 & $H$ & H & + & + & + & + & + & \pm & - & - \\
\hline 健全イネ㳆液 & - & - & - & - & - & - & - & - & - & - \\
\hline
\end{tabular}


第 13 表 沈降 反応

\begin{tabular}{|c|c|c|c|c|c|c|c|c|c|c|c|}
\hline $\begin{array}{l}\text { 抗血清終末 } \\
\text { 稀 釈 倍 数 }\end{array}$ & 16 & 32 & 64 & 128 & 256 & 512 & 1024 & 2048 & 4096 & 8192 & 対照 \\
\hline 罹病イネ汁液 & $H$ & H & $H$ & + & + & + & + & + & + & - & - \\
\hline 健全イネ汁液 & \pm & \pm & - & - & - & - & - & - & - & - & - \\
\hline
\end{tabular}

抗原稀釈倍数： 5 倍

東に注射した。この注射後， 3 週目に 1 部採血を行な つて力価検定を試みた。その結果は第 13 表に示すと おりである。

この結果によれば, 罹病イネ汁液に対しては1/4096 まで反応を示したが，健全イネ汗液には反応がなかつ た。これによつて, かなり力価の高い抗血清を得られ ることがわかつた。

\section{鵎畉培養試験}

Murphy and Ross は鶏卵胚に腫瘍組織を培養する 方法を案出した11。すなわち鷄に生ずる肉腫組織を発 育鵎卵の獎尿膜に移植して培養することを企て, 初め てこれに成功したのである。

その後 Woodruff and Goodpasture は fowl poxの ウイルスを発育鵎卵の漿尿膜に培養した ${ }^{16) 。 こ れ か ゙ ウ ~}$ イルスの鷄卵培養の最初の報告である。それ以後この 方法は種々改良されて, 種々の病原体の培養に用いら れ, 多くの動物ウイルスはこの方法で培養できること がわかつた。

また Burnet らは漿尿膜以外の部分に培養する方法 を発見した4。

植物ウイルスに执いては, Takahashiがこの方法を 用いてタバコモザイク病ウイルスを漿尿膜に接種して 培養を試みたが不成功に終つた ${ }^{13)}$ 。また鮎沢らはカイ コ膿病ウイルスを発育鵎卵で培養を試みたが成功しな かつだ2)。

著者はイネ萎縮病ウイルスをこの方法で培養しよう と試みた。

実験材料扎よび方法 : 鶏朐培養には白色レグホンの 受精朐を使用した。睬卵器は菌類培養用恒温器を用 い, 睬化温度は $37 \sim 38^{\circ} \mathrm{C}$ で湿度の調節のために径 12 $\mathrm{cm}$ のシャーレのふたに水を入れて恒温器の最下段に 置いた。即は 1 般に行なわれているように気室部を斜 め上にした位置に保ち，1日に $2 \sim 3$ 回転畉を行なつ た。睜化後，4日扣よび 8 日目に検卵して無精卵扣よ び発育停止畉を除去し, 䊩化後 11 日目に漿尿膜に接 種を行なつた。接種法は一般に行なわれている方法に よつた。
接種源は保毒虫を䄷砕し，軽く遠心分離を行なつた 上清を用いた。接種源には $1 \mathrm{ml}$ につき水溶性ペニシリ ソ 1,000 単位を加えて微生物の 繁殖を防ぎ, $0.1 \mathrm{ml}$ づつ接種した。

接種後 7 日目に開畉して漿尿膜を取り出し, 生理食 塩水で $2 \sim 3$ 回洗い, 変化があるか否かを 観察した 後, この膜を噢砕して, 生理食塩水で稀釈し, 遠心分 離を行なつて, 上清をとり, 無毒虫に注射して, この 液が感染力を有するか否かを調べた。

実験 保毒虫を磨砕し, 1:50 に稀釈し，10,000 $\mathrm{rpm} 30$ 分, 遠心分離を行ないその上清を $0.1 \mathrm{ml}$ ず つ発育鵎畉に接種した。そして接種後 6〜7日目に開 卵し，漿尿膜を取り出し，磨砕して $1: 10$ に生理食 塩水で稀釈して，軽く遠心分離を行ない，その上清を 無毒虫に注射した。その結果は第 14 表に示すと打り である。

第 14 表 鶏卵培養試験

\begin{tabular}{|c|c|c|c|c|c|}
\hline 実験 & 卯孚化鵎 & |開卵時生 & 射忠数 & 20日以上 & 咸染由 \\
\hline 番号 & 卯 数 & 育 卵 数 & 射生 & 生存虫数 & 柋架虫 \\
\hline I & 10 & 8 & 68 & 39 & 0 \\
\hline III & 20 & 4 & 53 & 17 & 0 \\
\hline III & 20 & 9 & 30 & 2 & 0 \\
\hline IV & 20 & 4 & 50 & 26 & 0 \\
\hline
\end{tabular}

以上のごとく，25 個の 発育鵎卵から 漿尿膜をとり 出して，その抽出液を 201 頭のヨコバイに注射した が 1 頭も感染しなかつた。

\section{考察}

ヨコパイやウンカによつて媒介される植物ウイルス のうちで, 精製され, 形態が観察されたウイルスは少 ない。著者は超遠心機を用いて，分画遠心分離によつ てイネ蒌縮病ウイルスの精製を試みたがある程度の純 化に成功した。この部分的精製液を電子顕微鏡で観察 した結果, 60〜80 m $\mu$ の球形あるいは高角形粒子が見 られた7。またこれと同じ粒子が保毒虫和よび罹病イ ネの組織の超薄切片の中に観察された。しかし分画遠 沈を反覆しても試料が十分純化されず，活性が低下す るのでさらに純度を高めるために，硫安やクロロホル 
ムなどを用い前処理を行なうことが必要である。

吉井らは萎縮イネの組織から Kirby 法によつて核 酸を抽出し，これを用いて無毒虫を感染させ，この抽

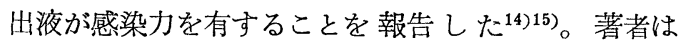
Schramm らと類似の方法を用いて，部分的精製ウイ ルス液から核酸の抽出を試み，1M食塩で沈殿させて 得た試料には感染力が有つたが，アルコール沈殿で得 た試料には感染力がなかつた。紫外部吸収曲線を見る に,アルコール沈殿によつて得た試料は食塩沈殿のも のより不純物がよく除かれているようである。

江崎らは罹病磨砕汁液をる過器を用いて精製した試 料を抗原として家鬼に注射して抗血清を得ている5)。 この血清は健全イネ汁液とは反応しなかつたそうであ るが，力価が低いものであつた。著者は分画遠心によ る部分的精製液を Adjuvant と混合して家東に注射し た結果, 高力価の抗血清を得た。これによつて汁液内 のウイルスを容易に検出することができるので，この ウイルスの研究を進める上において今後重要な役割を 演ずるものと考えられる。

\section{摘 要}

1. イネ萎縮病ウイルスは $10,000 \mathrm{rpm} 30$ 分での 遠心力では少し沈殿するが， $5,000 \mathrm{rpm} 30$ 分では沈 殿しなかつた。保毒虫および罹病イネ磨砕汼液中のウ イルス粒子は $20,000 \mathrm{rpm} 120$ 分で沈殿した。このウ イルス粒子の $\mathrm{M} / 30$ リン酸緩衝液中の沈降定数は405 $\times 10^{-13} \mathrm{sec}$ であつた。

2. 部分的精製ウイルス液からフェノール法で，核 酸の抽出を試みた。抽出液を食塩で沈殿させた試料は 感染力を有し, その紫外部吸収曲線は $270 \mathrm{~m} \mu$ にpeak を示した。抽出液をアルュールで沈殿させたものは感 染力がなく, その紫外部吸収曲線は $258 \mathrm{~m} \mu$ に peak があつた。

3. 部分的精製ウイルス液に Bact-Adjuvant を混 じて家來に注射したところ，終末稀釈倍数 1/4096 の 力価を有する抗血清が得られた。

4. このウイルスは発育鵎卵の嶈尿膜上に培養出来
なかつた。

(1962. 3.3 受理)

\section{引用交献}

1）鮎沢啓夫 (1957). ウイルス $7: 450$.

2）—・長楽勇・阿部交子 (1957). 亰系研究 $20: 71 \sim 72$.

3) Black, L. M. and Brakke, M. K. (1954). Phy topath. $44: 482$.

4) Burnet, F. M. (1934). Brit. J. Exp. Path. $15: 52 \sim 55$.

5）江崎悌三・鮫島徳造（1938）。農林省委託浮塵子 駆除予防試験報告 $9: 23 \sim 29$.

6) Fraenkel-Conrat, H., Singer, B. and Williams, R. C. (1957). Biochem. Biophys. Acta 25 : 87 96

7) Fukushi, T., Shikata, E., Kimura, T. and Nemoto, M. (1960). Proc. Japan Acad. 36 : $352 \sim 357$.

8) Gierer, A. und Schramm, G. (1956). Z. Naturforuch 11 b: 138 142.

9) Gierer, A. und Schramm, G. (1956). Nature $177: 702 \sim 703$

10) Kirby, K. S. (1956). Biochem. J. $64: 405$ $\sim 408$.

11) Murphy, J.B. and Ross, P. (1912). J. exper. Med. 15 : 119.

12）渡辺格・川出由己（1956）。超遠心機とそれによ る蛋白質扣よびヴィールスの研究（佐々木重雄 編), 東京, 163 171 .

13) Takahashi, W.N. (1940). Phytopath. 30 : $184 \sim 185$.

14）吉井啓・木曾船・宮内修三（1959）、日植病報 25 $: 52$.

15) Yoshii, H. and Kiso, A. (1960). Virus $9: 582$ $\sim 589$.

16) Woodruff, A.M. and Goodpasture, E. W. (1931). Amer. J. Path. $7: 209 \sim 222$. 


\section{Summary}

1. When extracts from leaves of diseased rice plants or from viruliferous leafhoppers were centrifuged at 10,000 rpm for 30 minutes the virus was slightly precipitated, but it was completely precipitated by centrifugation at $20,000 \mathrm{rpm}$ for 120 minutes. Partially purified preparations of the virus were secured by two cycles of alternate low and high speed centrifugations. The sedimentation constant of the virus particle in $\mathrm{M} / 30$ phosphate buffer was determined to be $405 \times 10^{-13}$ sec.

2. Nucleic acid extracted from partially purified virus preparations with water saturated phenol and sedimented with $\mathrm{NaCl}$ was found to be infective, when injected into the abdomen of non-viruliferous leafhoppers, but the preparations sedimented with ethanol were devoid of infectivity.

3. When rabbits were injected intramuscularly with an emulsion of partially purified antigen in Freund's adjuvant, a high titer antiserum was obtained.

4. The virus could not be cultivated on the chorioallantoic membrane of developing chick embryo.

(Faculty of Agriculture, Hokkaido University, Sapporo, Japan)

\section{新 刊 紹 介}

明日山秀文・向 秀夫・鈴木直治 編集：

植物病理実験法, A 5 判, 843 面, 日本植

物防疫協会, 1,500 円, 1962 .

植物病理学の最近の進歩は, 菌学や植物生理生態 学, あるいは植物解剖学などの古典的な技術はるち ろん, 生理学, 生物化学, 生物物理化学など, 多方 面にわたる広い知識と新しい技術とをとくに要求し ている。かつ実験科学に打いては, 実験方法の適否 がその研究の成否を大きく支配するものであるか ら, この意味飞招いても植物病理学飞関する実験方 法のよい指導書を求める声は強かつた。

本書はこの要望にこたえる意味で編集されたるの と思われ，全編を 19 章に分けて，実験に必要なあ らゆる事項を一応とりあげて説明しょらと苦心して

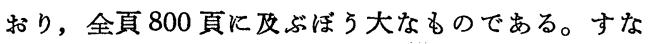
わち, まず病理学に必要な実験器具や施設を解説 し, ついで顕微鏡の取り扱い方, とくに位相差䫓微 鏡, 偏光顕微鏡, 紫外線顕微鏡など新しい顕微鏡に ついて説明を試みている。さらに病原体の培養法, 怙よびその培地, 病原菌の分離培養の技術, 環境条
件の測定法招よびその調節法などを説明し，殺菌剂 の効力検定方法, 疾病防除の試験方法飞 及几でい る。そのほか植物の解剖技術, 組織化学に関する実 験方法, 病原菌の代謝生理, 寄生の病態生理, 細胞 の生理化学比関する諸実験方法, 病原菌の生産する 代謝毒素に関する実験方法などについてる説明を試 み, 血清反応, ウイルス実験法, 電子顕微鏡技術な ど飞も言及している。

以上のよ $5 に$ ，実験に必要な事項をすべて取りあ げょうとつとめた結果, 実験方法というょりは, む しろ現象の説明飞終わつているような点る少なくな いが，いずれにしても本書 1 冊あれば，植物病理に 関する実験法は一応わかるので, きわめて利用価值 の高い良書といらことができょう。しかし，しいて 難をい之ば, 植物病理学の領域に括いて今後もつと も必要を感じまた発達するであろう病態生理学や 生理化学に関する分野について, 新しい実験方法の 紹介がやや少ない上5に思われることである。本書 が永く植物病理実験の指導書として利用されるため には, 是非この点の補足が望ましい。(赤井重恭) 